допомагає учням отримати більш повне уявлення про формування й розвиток суспільства, дає їм змогу сформувати цілісну картину навколишнього світу, визначити свою життєву позицію.

\title{
Література:
}

1. Байкачова К. В. Сучасний стан та проблеми економічної освіти молодших школярів. URL: http://molodyvcheny.in.ua/files/journal/ 2018/12.1/18.pdf.

2. Божко О. Програма 3 курсу «Основи економічних знань». Початкова освіта. 2003. № 31 (223). С. 2-3.

3. Варецька О. В. Програма курсу за вибором з економіки «Початки економіки» для початкової школи загальноосвітніх навчальних закладів. Запоріжжя: Просвіта, 2008. 28 с.

4. Кулішов В. В. Методичні засади формування економічної компетентності у процесі підготовки фахівців технологій: монографія. К.: Каравела, 2011. 567 с.

5. Пасічник Н. О. Формування економічної культури школярів як умова розвитку цивілізованих ринкових відносин. Рідна школа. 2007. № 4. C. 45-47.

6. Сасова I. А. Економічна підготовка учнів шкіл : навчальний посібник. Київ, 2000. 87 с.

7. Сигида С.В. Уроки економіки у початковій школі. Економіка. 2005. № 2. C. 21-22.

8. Слободянюк Н. Г. Основи економічних знань у початкових класах. Початкова школа. 2003. № 11. С. 20-21.

DOI https://doi.org/10.30525/978-9934-26-114-5-26

\section{СИСТЕМА ВИЩОЇ ЕКОНОМІЧНОЇ ОСВІТИ В УРСР У ДРУГІЙ ПОЛОВИНІ ХХ СТОЛІТТЯ}

\author{
Федун Д. С. \\ аспірант кафедри психології, педагогіки та філософії \\ Кременчуиький національний університет \\ імені Михайла Остроградського \\ м. Кременчук, Україна
}

Необхідність вивчення системи підготовки економічних кадрів в Україні, в період 3 плановою системою економіки, обумовлена все більше зростаючою сьогодні необхідністю підготовки фахівців, які 
володіють не тільки навичками ринкових механізмів, але й знають командно-планові методи регулювання. Потреба в розвитку даного педагогічного спрямування в українській вищій економічній освіті пов'язана зі зміщенням орієнтацій провідних економік світу на соціально орієнтовані змішані системи економічних взаємин. Дана тенденція особливо важлива, враховуючи приклад все зростаючої керівної ролі держави в питаннях соціального врегулювання, а також плануванні попиту i пропозиції на макрорівні, який здійснюється такими країнами, як: Великобританія, Німеччина, Франція, США, Японія та іншими провідними економіками світу.

Вивченням історичного досвіду, при підготовці економічних кадрів в Україні, цікавилися такі дослідники, як: Домбровська С. М., Доменнікова Е. И., Касіянц С. Е., Кігель Р. Ю., Мисько О. М., Сінгаївська А. М., Шишкін М. В. та ін.

Освітній процес 1950-х - 1980-х років в Україні був орієнтований виключно на історично сформовані соціально-політичні умови. Стратегія розвитку економіки та методи іiі планування в корені відрізнялися від країн з ринково-орієнтованої економічною моделлю господарських відносин.

Україна в другій половині 50-х років XX століття, перебуваючи в складі СРСР, стала на шлях екстенсивного розвитку економіки, що в сукупності 3 характером соціально-політичної системи, справило значний вплив на формування підготовки економістів в системі вищої освіти. Українська освіта, в представленому періоді, як структурний елемент командно-планової економічної системи, при виборі стратегії і методик навчального процесу була зобов'язана керуватися сформованими соціалістичними цілями і пріоритетами.

Верховна Рада УРСР своїм Законом від 17.04.1959 року «Про зміцнення зв'язку школи 3 життям и про дальший розвиток системи народної освіти в Український РСР» закликав вищу школу Української республіки виховувати різнобічно освічених особистостей, які володіють знаннями у відповідних галузях науки і техніки. У положеннях цього Закону особлива увага приділялася необхідності підвищення рівня підготовки економічних кадрів для таких галузей як сільське господарство, будівництво, промисловість які швидко розвивались у той період. До випускників вищих навчальних закладів пред'являлися обов'язкові вимоги оволодіння високим рівнем теоретичних знань i практичних навичок.

Освітній процес в УРСР, у другій половині ХХ століття, був орієнтований на підготовку економістів на базі соціалістичних принципів і положень про планове регулювання. 
Основними досліджуваними факторами, що впливали на складання планів в країні були: передумови і необхідність планування; планування, як прояв що здійснюється на основі демократичного централізму господарсько-організаторської функції держави; наукова технічна i економічна обгрунтованість планів; принцип провідних ланок в плануванні; єдність державного народногосподарського плану i його збалансованість; пропорційність, як найважливіша сторона планомірного розвитку економіки; визначальна роль перспективного планування при його поєднанні з поточним; участь мас в розробці і здійсненні планів; поєднання планування 3 економічним стимулюванням розвитку виробництва [1].

Орієнтуючись на Закон ВР УРСР «Про народну освіту» від 1974 року і Постанову РМ СРСР «Про затвердження положення про вищі навчальні заклади СРСР» від 1969 року можна стверджувати, що основними принципами, як усієї вищої освіти, так і економічної зокрема, були: рівність всіх громадян на отримання освіти; державний статус вищих навчальних закладів; вільний вибір мови навчання будь-якої з народностей СРСР; безоплатність здобуття освіти; зв'язок виховання і навчання 3 життям та практикою; науковий характер освітнього процесу та його постійне вдосконалення; високоморальний та гуманістичний характер виховання і навчання; світський характер навчання, що виключав вплив релігії.

Підготовка економістів з вищою освітою в Україні в 1950-х - 1980-х роках здійснювалася в таких установах як: академії, університети, інститути, заводи-втузи та ін.

Основними завданнями, які ставили перед собою ці заклади вищої освіти, були:

- підготовка фахівців 3 глибокими теоретичними знаннями i практичними навичками за фахом і організації масово-політичної та виховної роботи, які володіють новітніми досягненнями в вітчизняної та зарубіжної науки і техніки;

- виховання у студентів високих моральних якостей, свідомості, культури, соціалістичного інтернаціоналізму, радянського патріотизму;

- постійне вдосконалення якості підготовки фахівців з урахуванням вимог сучасного виробництва, науки, техніки, культури і перспектив їх розвитку;

- виконання науково-дослідних робіт, що сприяють більш якісній підготовці фахівців;

- створення високоякісних підручників і навчальних посібників;

- підвищення кваліфікації викладацького складу; 
- виховання у студента почуття обов'язку і готовності до захисту своєї Батьківщини;

- фізична підготовка і здійснення заходів по зміцненню здоров'я студентів [2].

Студенти, в процесі навчання в ВНЗ, зобов'язані були систематично і глибоко оволодівати знаннями і практичними навичками за обраною спеціальністю; відвідувати навчальні заняття та виконувати у встановлені терміни завдання навчального плану; підвищувати свій ідейно-політичний, науковий і культурний рівень; брати участь в суспільно корисній праці; виконувати правила внутрішнього розпорядку ВНЗ та ін. [3].

Студентам, які успішно виконали навчальну програму, склали державні іспити та захистили дипломну роботу, присуджувався освітній рівень спеціаліста 3 економіки 3 відповідною його підготовці кваліфікацією.

Система вищої економічної освіти в Україні в 1950-х - 1980-х роках являла собою досить організовану систему, що вела підготовку висококваліфікованих економічних кадрів для соціалістичної системи планового регулювання економічними процесами, які вже відразу, після проходження навчання, мали новітні теоретичні знання і володіли повноцінними практичними навичками. Законодавча база та позитивні соціальні умови в достатній мірі також сприяли розвитку економічної освіти в Україні в 50-х - 80-х роках XX століття.

Впровадження в сучасну систему вищої економічної освіти елементів педагогічного досвіду, який історично зарекомендував себе, позитивно вплине, як на рівень підготовки висококваліфікованих економістів, так і на підвищення конкурентності всієї української освіти в цілому.

\section{Література:}

1. Курский А. Д. Планирование в СССР: опыт шести десятилетий. Экономические науки. 1977. № 10. С. 3 - 13 .

2. Положение о высших учебных заведениях СССР: Приказ от 22.01.1969

№ 64 / Совет Министров CCCP. URL: http://www.economics.kiev.ua/dow nload/ZakonySSSR/data03/tex15196.htm (дата звернення: 15.05.2021).

3. Про народну освіту: Закон УРСР від 28.06.1974 р. № 2778-VIII. Верховна Рада Української PCP. URL: http://search.ligazakon.ua/1_doc2.n sf/link1/T742778.html (дата звернення: 06.05.2021). 